\title{
Pathogenic Variability of Meloidogyne incognita Populations Occurring in Pepper-Production Greenhouses in Israel Toward Me1, Me3 and N Pepper Resistance Genes
}

Patricia Bucki, Department of Entomology, Units of Chemistry and Nematology, Agricultural Research Organization (ARO), the Volcani Center, Israel; Ilan Paran, Department of Vegetable and Field Crops, Plant Sciences, ARO, the Volcani Center, Israel; Rachel Ozalvo, Department of Entomology, Units of Chemistry and Nematology, ARO, the Volcani Center, Israel; Ionit Iberkleid, Department of Entomology, Units of Chemistry and Nematology, ARO, the Volcani Center, Israel; and Department of Plant Pathology and Microbiology, The Robert H. Smith Faculty of Agriculture, Food and Environment, The Hebrew University of Jerusalem, Rehovot, Israel; Liana Ganot, Negev R \& D Center, M.P.O 4, Negev 8544100, Israel; Sigal Braun Miyara, Department of Entomology, Units of Chemistry and Nematology, ARO, the Volcani Center, Israel

\begin{abstract}
Natural variation in the root-knot nematode Meloidogyne incognita is problematic for breeding programs: populations possessing similar morphological characteristics can produce different reactions on the same host. We collected 30 widely dispersed $M$. incognita populations from protected pepper production systems in major pepper-growing regions of Israel and accurately identified their virulence characteristics by modified differential host test in a growth chamber on tomato, tobacco, cotton, melon, pepper, and peanut. Galling indices and reproduction were determined on the different hosts. All populations fit the published scheme for $M$. incognita race 2, except for reproduction on cotton plants by five out of 25 tested $M$. incognita populations, indicating host-range variations. Reaction of three genes that confer resistance to $M$. incognita-Me1, Me3 and $N$-to the collected populations

was evaluated. Several $M$. incognita populations induced galling and reproduced successfully on pepper genotypes carrying $\mathrm{Me} 3$ and $\mathrm{N}$, whereas plant resistance conferred by $M e 1$ was more robust for all examined populations. Moreover, the effect of genetic background on $\mathrm{Mel}$ resistance demonstrated a relative advantage of several genotypes in nematode infestations. Efficiency of $\mathrm{Me} 3$ under local nematode infestation was further studied with a homozygous line carrying two $\mathrm{Me} 3$ alleles. Reproduction of virulent populations on the homozygotes (Me3/ $\mathrm{Me3})$ and heterozygotes $\left(\mathrm{Me}^{2} / \mathrm{Me}^{+}\right)$was similar, suggesting a limited quantitative effect of $\mathrm{Me} 3$. These results present the first characterization of host range, reproduction, and molecular aspects of $M$. incognita from Israel and highlight the importance of taking a multidimensional approach in pepper-breeding programs for resistance to $M$. incognita.
\end{abstract}

Meloidogyne species of root-knot nematodes (RKNs) are considered one of the main pathogens of solanaceous crops worldwide, with sweet pepper (Capsicum annuum L.) being highly susceptible (Khan and Haider 1991). Meloidogyne incognita is the predominant RKN species in protected crops of sweet pepper grown in majors regions in Israel, causing significant losses in crop production (Oka et al. 2004). Traditionally, this species has been controlled by chemical soil disinfectants. However, in recent years, use of most nematicides has been largely restricted because of their nonspecific and notoriously toxic effects, which pose a threat to the soil ecosystem, ground water, and human health (Chitwood 2003; Koenning et al. 1999; Weingartner et al. 1980). As a result, the nematode problem in solanaceous crops is on the rise, leading to an urgent search for new alternatives.

As a consequence, breeding programs for the selection of cultivars and/or rootstocks that are resistant to $M$. incognita have become a major goal for breeders (Colla et al. 2012; Djian-Caporalino et al. 2011). In pepper, only the dominant $M e 1, M e 3$, and $N$ resistance (R) genes are effective against $M$. incognita (Djian-Caporalino et al. 1999; Hare 1956; Hendy et al. 1985; Thies 2011). These R genes, identified in geographically and genetically distant lines, are colocalized in a cluster on the P9 chromosome of pepper (Fazari et al. 2012). However, the emergence of virulent RKN populations has put the effectiveness

Corresponding author: Sigal Braun Miyara;

E-mail: sigalhor@volcani.agri.gov.il

*The $\boldsymbol{e}$-Xtra logo stands for "electronic extra" and indicates that four supplementary tables and one supplementary figure are published online.

Accepted for publication 25 April 2017.

C 2017 The American Phytopathological Society of $N$ and $M e 3$ into question (Castagnone-Sereno et al. 1996; Thies 2011). Similarly, under greenhouse cultivation, the emergence of virulent populations has been reported when crops of resistant rootstocks are grown for several consecutive years (Ros-Ibáñez et al. 2014).

Among the factors involved in overcoming resistance, Barbary et al. (2014) raised the importance of genetic background in the durability of the resistance conferred by the $M e$ genes, by showing that certain backgrounds into which $\mathrm{R}$ genes are introgressed can prevent the breakdown of resistance. Moreover, other strategies for the use of $\mathrm{R}$ genes, such as pyramiding $\mathrm{Mel}$ and $\mathrm{Me} 3$ in the same genotype or alternating them in consecutive crops, have been shown to increase durability of the cultivars' resistance and improve nematode control (Djian-Caporalino et al. 2014).

Nevertheless, efforts to control these nematodes through the breeding of resistant varieties and crop rotation have been consistently hampered by high variations in virulence. Variation in pathogenicity among populations of Meloidogyne is not uncommon. Riggs and Winstead (1959) reported that new strains of $M$. incognita developed in the greenhouse are capable of attacking resistant tomato plants. Later, Southards and Priest (1973) showed considerable variation in the pathogenicity of 17 isolates of $M$. incognita, suggesting the existence of six physiological races, and that more would be distinguished with additional collections. Swanson and Van Gundy (1984) demonstrated reproductive variability in four races of $M$. incognita on two soybean cultivars. More recently, Sano and Iwahori (2005) showed that in Japan, there is regional variation in the pathogenicity of $M$. incognita populations on sweet potato.

Physiological variation among species of $M$. incognita presents problems for taxonomists, plant breeders, and other investigators, since certain populations possessing similar morphological characteristics produce different reactions on the same host (Southards and Priest 1973). Accumulating studies indicate that to succeed with breeding programs and crop-rotation practices to manage $\mathrm{RKN}$ 
disease, detailed information is needed on the nature and extent of the variation among the studied RKNs (Jacquet et al. 2005; Khan and Haider 1991; Petrillo and Roberts 2005; Ros-Ibáñez et al. 2014; Thies 2011). However, for this to be successful, the species, race, and virulence characteristics of the locally occurring nematode population need to be known.

In the last few years, new commercial elite pepper cultivars, considered to be resistant cultivars, have been introduced by seed companies to the market of peppers produced in protected systems in Israel. However, despite the fact that they carry an R gene, high variation in their resistance/susceptibility response to $M$. incognita infection has been recorded. These observations illustrate the complex interaction between the resistant line and local $M$. incognita populations that occurs under real agronomic conditions.

The purpose of the present investigation was to evaluate the extent of variation in pepper parasitism among $M$. incognita populations collected from pepper-production greenhouses in Israel. This was achieved by: i) comparing host suitability for $M$. incognita populations through differential host test; ii) determining the effectiveness of the RKN R genes $M e 1, M e 3$, and $N$ in combatting $M$. incognita populations; iii) evaluating the effect of $M e 3$ allelic stage on resistance/susceptibility responses to local nematode populations; iv) evaluating the effect of $M e 1$ genetic background on the resistance/ susceptibility response to local nematode populations; and v) assessing avirulent nematode population's ability to overcome plant resistance under real agronomic conditions.

\section{Materials and Methods}

Nematode isolate collection and inoculum preparation. For a detailed characterization of $M$. incognita populations distributed in local pepper-protected systems, a nematode survey was carried out during the years 2012-2014. Major pepper-production regions that have been extensively cultivated with susceptible pepper genotypes (commercial cultivars) or with genotypes carrying $\mathrm{R}$ genes for one season - the Arava, northern Negev, Negev Hill, HaBikha, and Carmelwere the source for the 30 sampled Meloidogyne populations; detailed information with regard to their locality and pepper cultivar serving as host plant is provided in Table 1. Next, each collected population was used to reinoculate susceptible pepper plants under control conditions. To eliminate population heterogeneity, a single egg mass was carefully selected from the first generation raised from each greenhouse population, and this population was routinely reared on susceptible pepper plants in the Nematology Department at the ARO Volcani Center. Given that $M$. incognita has a mitotic parthenogenetic mode of reproduction (Triantaphyllou 1984), all egg masses produced on subsequent generations were considered cloned lines. Control isolates included the avirulent $M$. incognita isolate Mi2010 and the avirulent M. javanica Mj2010, which are routinely maintained and multiplied on susceptible pepper cv. Maor and tomato cv. Avigail, respectively, under control conditions. Both isolates were previously identified by perennial patterns (Taylor and Netscher 1974) and molecular markers (Zijlstra et al. 2000). Of the 30 populations, 25 were successfully recovered on susceptible pepper plants, and these were used for further characterization. As a first step, DNA was extracted from egg masses of all populations and each population was identified as $M$. incognita using species-specific SCAR primers Finc/Rinc (data not shown). For infection studies, nematode inoculums were obtained and processed according to Hussey and Barker (1973). Eggs were extracted from infected roots by processing in $0.05 \%(\mathrm{v} / \mathrm{v}) \mathrm{NaOCl}$ in a commercial Waring blender (Torrington, CT) for 2 min at high speed. Blended roots were passed through a set of three sieves of 300,60 , and $30 \mu \mathrm{m}$, allowing collection of pure egg solution in the lower sieve. Egg suspensions were centrifuged and resuspended in $10 \mathrm{ml}$ double-distilled $\mathrm{H}_{2} \mathrm{O}$ before counting. Six- to seven-week-old plants (four to six true leaves) were inoculated with a water suspension consisting of 3,500 eggs. Following inoculation, plants were maintained at 23 to $25^{\circ} \mathrm{C}$ with a photoperiod of $16 \mathrm{~h}$ light and $8 \mathrm{~h}$ dark, watered daily, and fertilized weekly as described above.

Evaluation of plant response to $M$. incognita population. Two months after inoculation, allowing completion of one RKN generation, plants of each genotype were uprooted and their roots were gently washed of soil and examined under a magnifying glass to calculate the galling index (GI) and to estimate infestation symptoms.

Table 1. Meloidogyne isolates collected in the current survey along with the control avirulent isolates, including geographical origin and associated pepper cultivar hosts

\begin{tabular}{|c|c|c|c|}
\hline Isolate & Meloidogyne spp. & Region & Associated host \\
\hline Mi2010 & M. incognita & Control isolate & Maor (Hazera) \\
\hline Mj2010 & M. javanica & Control isolate & Avigail 870 (Hazera) \\
\hline Pop1 & M. incognita & Emek Haela-Modiin & Lapid (Magnum seeds) \\
\hline Pop2 & M. incognita & Talmey-Bilu & Nirvin (Rijk Zwaan) \\
\hline Pop4 & M. incognita & Moshav Tomer & AVANTA 35105 (Rijk Zwaan) \\
\hline Pop5 & M. incognita & Alumim & Banji (Enza Zaden) \\
\hline Pop6 & M. incognita & Nitzan & Milena (Enza Zaden) \\
\hline Pop8 & M. incognita & Moshav Tsrufa & Bunji (Enza Zaden) \\
\hline Pop10 & M. incognita & Moshav Tsrufa & Bunji (Enza Zaden) \\
\hline Pop11 & M. incognita & Moshav Tsrufa & Bunji (Enza Zaden) \\
\hline Pop13 & M. incognita & Moshav Tsrufa & 7182 (Syngenta) \\
\hline Pop14 & M. incognita & Megadim & Mediterranean Kadilak \\
\hline Pop15 & M. incognita & MOP Darom & - \\
\hline Pop16 & M. incognita & Negev Hill & - \\
\hline Pop17 & M. incognita & Habsor & - \\
\hline Pop18 & M. incognita & Moshav Dekel & - \\
\hline Pop19 & M. incognita & Moshav Tomer & 54200 (Rijk Zwaan) \\
\hline Pop20 & M. incognita & Moshav Tomer & 35151 (Rijk Zwaan) \\
\hline Pop21 & M. incognita & Moshav Tomer & 35159 (Rijk Zwaan) \\
\hline Pop22 & M. incognita & Moshav Tomer & Bunji (Enza Zaden) \\
\hline Pop23 & M. incognita & Moshav Tomer & Bunji (Enza Zaden) \\
\hline Pop25 & M. incognita & Moshav Faran & Zohar (Hazera) \\
\hline Pop26 & M. incognita & Moshav Faran & 7158 (Syngenta) \\
\hline Pop27 & M. incognita & Moshav Faran & Dinamo (Machteshim) \\
\hline Pop28 & M. incognita & MOP Yair & Bunji (Enza Zaden) \\
\hline Pop29 & M. incognita & MOP Yair & $\mathrm{R} 5515$ \\
\hline Pop30 & M. incognita & Moshav Tomer & 54200 (Rijk Zwaan) \\
\hline
\end{tabular}


Root fresh weight was recorded and each root system was assigned a root GI value with $0=$ no galling, $1=$ trace infection with a few small galls, $2=<25 \%$ roots galled, $3=25$ to $50 \%$ galling, $4=50$ to $75 \%$ galling, and $5=>75 \%$ of roots galled (Oka et al. 2004). The effect of each interaction on the formation of galls by each population was tested with the nonparametric Wilcoxon rank sum test (Hollander and Wolfe 1973).

Following galling assessments, number of egg masses per plant were either measured using Phloxine B solution (Sigma-Aldrich, St. Louis, MO) (0.159 $\left.\mathrm{g} \mathrm{liter}^{-1}\right)$ for $20 \mathrm{~min}$, which stained the egg masses (Hartman 1983), or whole eggs were extracted from individual root systems using the bleach and blending method according to Hussey and Barker (1973). Egg suspensions were centrifuged and resuspended in $10 \mathrm{ml}$ double-distilled $\mathrm{H}_{2} \mathrm{O}$ before counting. After appropriate dilution, eggs in 5- $\mu$ l aliquots from each sample were counted using a Wilovert Standard inverted microscope (Helmut Hund $\mathrm{GmbH}$, Wetzlar, Germany), and the number of eggs per root system was calculated.

Differential host tests. To determine variation among the collected populations, host range was characterized following the differential sets for Meloidogyne species (Barker et al. 1985) with the following modifications. Each of six crop plant cultivars were inoculated with 3,500 eggs of each of the $M$. incognita populations per pot containing $500 \mathrm{~g}$ loamy soil. Plant cultivars were as follows: Nicotiana tabacum cv. Samsun NN (tobacco); Gossypium hirsutum cv. Acala Rav-On 439 (cotton); Capsicum annum cv. Maor (pepper); Cucumis melo L. cv. Lavi Gal (muskmelon), Arachis hypogaea cv. Hanoch (peanut), and Solanum lycopersicum cv. Avigail 870 (tomato).

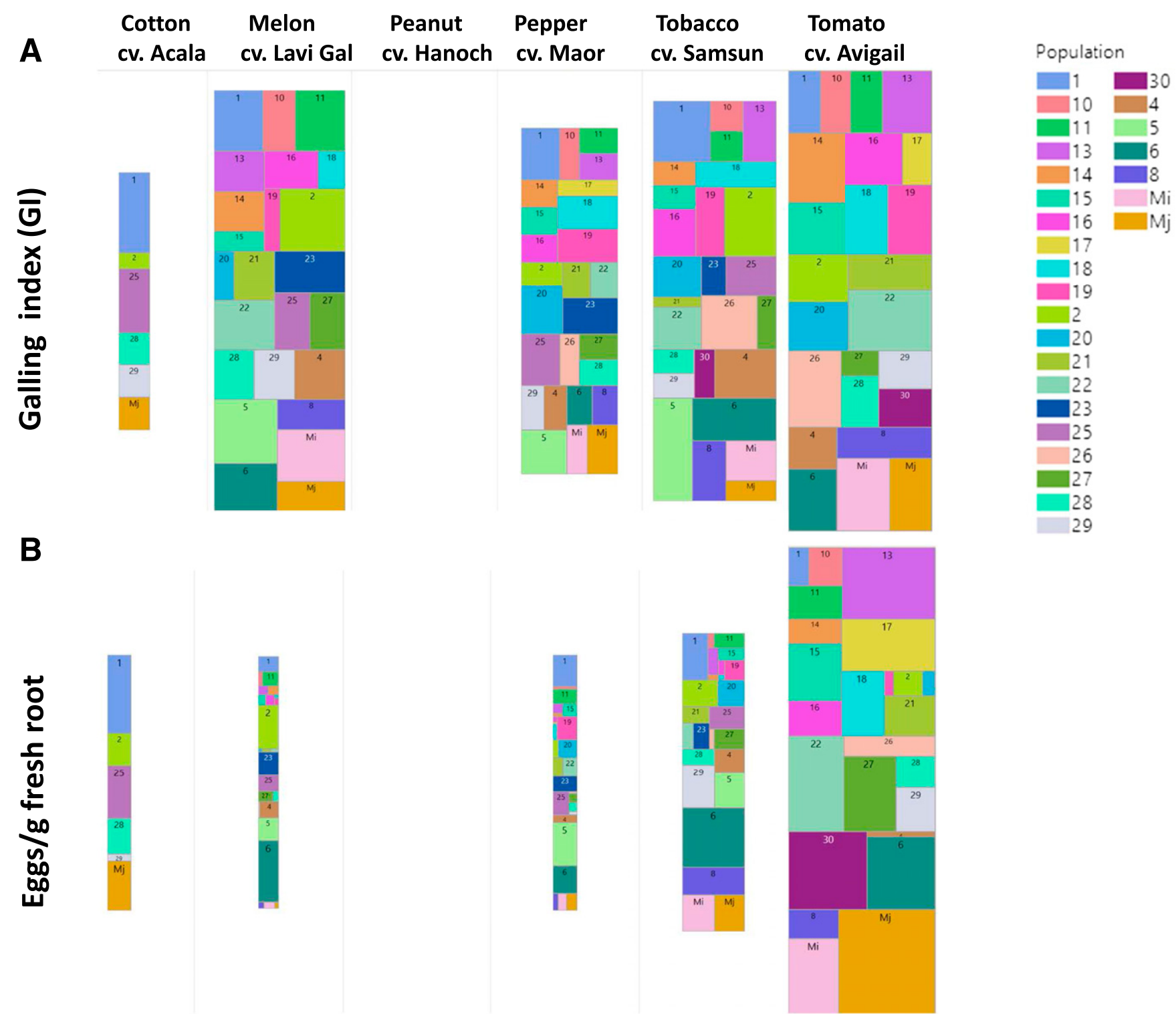

\section{Hosts}

Fig. 1. Host status and suitability of six cultivated plant species to $25 \mathrm{M}$. incognita populations collected throughout this study. All collected populations were assessed for their hostrace status and pathogenicity according to a modified North Carolina host test that relies on the combination of resistant and susceptible reactions of six differential hosts to the nematode populations. The tested hosts included the following plant species: Nicotiana tabacum cv. Samsun NN (tobacco); Gossypium hirsutum cv. Acala Rav-On 439 (cotton); Capsicum annum cv. Maor (pepper); Cucumis melo L. cv. Lavi Gal (muskmelon); Arachis hypogaea cv. Hanoch (peanut), and Solanum lycopersicum cv. Avigail 870 (tomato). The $x$-axis represents the host plant while the $y$-axis represents $\mathrm{GI}(\mathbf{A})$ or eggs per gram of fresh root system (B). Each color represents a different population, while the area of each square indicates proportional differences in $\mathrm{Gl}$ and eggs numbers among tested populations. Five replicates of each plant cultivar were included in each of the three-block designs $(n=15)$ for each population $\times$ host species combination. Results obtained from each block were not significantly different and data were pooled together for analysis $(P>0.6402)$. Two months after inoculation, plants were monitored for disease development. For nematode disease evaluation, galling on each root system by each population was scored and eggs extraction was used to evaluate reproduction for each host-nematode population combination. Gl was scored from 0 to 5 and egg counts per gram of fresh root are shown. 
Five replicates of each plant cultivar were included in each of the three-block designs $(n=15)$. Inoculated plants were maintained in a greenhouse at $25^{\circ} \mathrm{C}$ under $16 \mathrm{~h} \mathrm{light} / 8 \mathrm{~h}$ dark photoperiod and fertilized as needed. After 2 months, each nematode population $\times$ host plant reaction was classified for nematode infestation as described above. Results of differential host test for all collected populations along with GI and reproduction values are shown in Figure 1. Experiment studying cotton host suitability toward the collected $M$. incognita populations were repeated three times producing similar results and a representative data set is shown (Fig. 1; Suppl. Table S1, Suppl. Table S2).

DNA extraction, PCR amplification, and phylogenetic analysis. DNA extraction from egg masses of a single pot culture was performed according to Castagnone-Sereno et al. (1994), with the following modifications. Egg masses were dissected from infected pepper roots, washed in sterile water, and placed in Eppendorf tubes containing $20 \mu \mathrm{l}$ lysis buffer $(500 \mathrm{mM} \mathrm{KCl}, 100 \mathrm{mM}$ Tris- $\mathrm{HCl}$ $\mathrm{pH} 8.2,15 \mathrm{mM} \mathrm{MgCl}_{2}, 1 \mathrm{mM}$ dithiothreitol, proteinase $\mathrm{K}$ [Roche Diagnostics, East Sussex, UK] at $60 \mu \mathrm{g} \mathrm{ml}^{-1}$, and $4.5 \% \mathrm{v} / \mathrm{v}$ Tween 20) and incubated at $65^{\circ} \mathrm{C}$ for $1 \mathrm{~h}$. Proteinase $\mathrm{K}$ was inactivated by incubation at $95^{\circ} \mathrm{C}$ for $10 \mathrm{~min}$ and centrifugation for $10 \mathrm{~min}$ at $5,000 \times \mathrm{g}$. The supernatant was transferred to a new tube and $1 / 10$ vol of $3 \mathrm{M}$ sodium acetate, glycogen at 0.05 to $1 \mu \mathrm{g} \mu \mathrm{l}^{-1}$, and $1 \mathrm{vol}$ of isopropanol were added, followed by incubation at $-70^{\circ} \mathrm{C}$ for $30 \mathrm{~min}$ and then centrifugation for $15 \mathrm{~min}$ at $10,000 \times \mathrm{g}$. Precipitated genomic DNA was washed with $70 \%$ cold ethanol and resuspended in $30 \mu \mathrm{l}$ ultrapure water. The identification of a natural population of $M$. incognita (Kofoid \& White) Chitwood was confirmed by PCR analysis using the SCAR primers (Finc 5'-CTCTGCCCAATGAGCTGTCC-3' and Rinc 5'-CTCTGCCCTCACATTAGG-3') described by Zijlstra et al. (2000). The second set of primers designed on a highly conserved region of the internal transcribed spacers (ITS) (ITS2.1, 18S position 1636, 5'-CGTAGGTGAACCTGCGGAAGGATC-3' and ITS2.2, 28S position 2693, 5'-CCTGGTTAGTTTCTTTTCCTC (GC-3') that should in principle recognize all known ribosomal targets. The third set of primers used for the phylogenetic analysis was taken from a previous study by Hugall et al. (1999): MP581 and MITS2 were designed to amplify the ITS sequence assemblage (MP581, 5.8S position 2187, 5'-ATTTGTGCGAACTGCAGAA ACC-3'; MITS2, 28 S position 2645, 5'-GCTCTCGACTGAGTT CAGGTC-3'). All amplifications were performed with GoTaq Green Master Mix (Promega, Madison, WI) with approximately $40 \mathrm{ng}$ of genomic DNA template in a $25-\mathrm{ml}$ volume, annealing at $50^{\circ} \mathrm{C}$ for $40 \mathrm{~s}$ and extensions at $72^{\circ} \mathrm{C}$ for $1 \mathrm{~min}$. PCR products with MP581 and MITS2 were gel-purified and directly sequenced. The ClustalW program (Thompson et al. 1994) was used to generate alignment of the ITS sequences of all nematode populations. A subset of sequences from this study are available in the GenBank database (accession nos. KY009878-900).

Plant material and growth conditions. All pepper (C. annuиm var. annuиm [Grossum Group]) genotypes used in the current study are listed in Table 2. Fourteen pepper (C. annuum) genotypes originating from the Agriculture Research Organization (ARO), Volcani Center's pepper breeding program in Prof. Ilan Paran's laboratory were used to study the reaction of $M$. incognita populations and the respective $\mathrm{R}$ genes in different genetic backgrounds. Sources of resistance containing Mel (PM 217) and Me3 (PM 687) genes were kindly provided by Dr. Alain Palloix, INRA, France. Symbols for $\mathrm{Me} 1$ and $\mathrm{Me} 3$ allelic stage are as follows: for $\mathrm{Me} 3$ homozygous susceptible $\left(\mathrm{Me}^{+} / \mathrm{Me}^{+}\right)$, homozygous resistant $(\mathrm{Me} 3 / \mathrm{Me} 3)$, and heterozygous $\left(\mathrm{Me} 3 / \mathrm{Me}^{+}\right)$; for $\mathrm{Mel}$ homozygous susceptible $\left(\mathrm{MeI}^{+} /\right.$ $\left.\mathrm{MeI}^{+}\right)$, homozygous resistant $(\mathrm{Mel} / \mathrm{Mel})$, and heterozygous $(\mathrm{Mell}$ $\mathrm{Me}^{+}$).

'Nirvin RZ' F1 seeds (Rijk Zwaan, The Netherlands) were used as resistant controls carrying the $N$ gene, while 'Cannon 7158' (Syngenta, Switzerland) and 'Maor' (Hazera, Israel) seeds were used as susceptible controls, as these lines have displayed a large number of galls in previous assays. For evaluating reproduction of the entire $M$. incognita collected populations listed in Table 1, on genotypes carrying the three R genes, the accessions lines 1094, an F1 hybrid heterozygous for $\mathrm{Mel}\left(\mathrm{Mel}_{\mathrm{Mel}}^{+}\right)$, and $1043\left(\mathrm{Me}^{3} / \mathrm{Me}^{+}\right)$, and a third commercial line, Nirvin F1 $(N)$, were the sources for Mel, $M e 3$, and $N$, respectively, along with 'Maor' as the susceptible cultivar used as a control (Fig. 2). To evaluate the impact of allelic condition on the reproduction of $M$. incognita populations and $\mathrm{R}$ genes

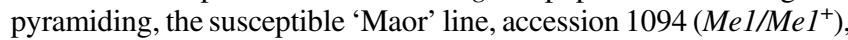
accession 1043, which is a fixed line homozygous for Mel (Mell $M e 1)$, accession 1044, which is a fixed line homozygous for $\mathrm{Me} 3$ $(\mathrm{Me} 3 / \mathrm{Me} 3)$, and accession $1968\left(\mathrm{MeI}_{\mathrm{MeI}}{ }^{+} ; \mathrm{Me} / \mathrm{Me}^{+}\right)$were evaluated for their response to pop1, pop30, and the avirulent control population Mi2010 and Mj2010 (Table 1; Figs. 3 and 4). To evaluate the effect of the genetic background, eight different genetic backgrounds (ARO breeding lines as listed in Table 2) were assayed for their response to four populations: pop1, pop16, pop30, and the avirulent control population Mi2010, at 8 weeks post infection (Fig. 5). For seedlings, respective seeds were germinated in trays of commercial, sterilized compost soil in a greenhouse and transplanted at the twoleaf stage into plastic pots filled with sandy loam soil. Transplanted seedlings were allowed to grow for an additional 2 weeks before nematode inoculation. Transplanted pepper plants were fertilized with slow-release fertilizer (Osmocote Smart-Release Plant Food, Scotts-Sierra Horticultural Products Co., Marysville, $\mathrm{OH}$ ) and maintained in the greenhouse under controlled conditions $\left(23\right.$ to $25^{\circ} \mathrm{C}$, photoperiod of $16 \mathrm{~h}$ light and $8 \mathrm{~h}$ dark). Two months after inoculation, resistance/susceptibility was evaluated according to GIs and number of eggs extracted from the root systems. Behavior of the R genes was studied with four replicates of five plants per replicate $(n=20)$, which were inoculated with each of the 25 populations collected in this study. Experiments studying pepper genotypes $\times M$. incognita interactions were repeated twice with similar results and a representative data set is shown (Figs. 2, 3, 4, 5; Suppl. Table S3, Suppl. Table S4). In addition, genotypes on which little or no infection occurred (rating

Table 2. Origin and characteristics of the Capsicum апnиum accessions used in this work

\begin{tabular}{|c|c|c|c|}
\hline Line name & Genotype & Original cross & $\begin{array}{l}\text { Gene for resistance to } \\
\text { Meloidogyne incognita }\end{array}$ \\
\hline 1043 & $\mathrm{Me1/Me1}$ & & Me1/Meloidogyne spp. \\
\hline 1094 & $\mathrm{Mel} / \mathrm{MeI}^{+}$ & & \\
\hline 1044 & $\mathrm{Me3/Me3}$ & & Me3/Meloidogyne spp. \\
\hline 1093 & $\mathrm{Me} 3 / \mathrm{Me}^{+}$ & & \\
\hline 1968 & $\mathrm{Mel}^{\mathrm{Mel} \mathrm{I}^{+} \mathrm{Me} 3 / \mathrm{Me}^{+}}$ & $1043 \times 1044$ & \\
\hline Canon 7158 & susceptible & & \\
\hline Maor & susceptible & & \\
\hline 1 & $\mathrm{Mel} / \mathrm{MeI}^{+}$ & $1716 \times 1043$ & \\
\hline 2 & $\mathrm{Mel} \mathrm{MeI}^{+}$ & USDA $\times 1043$ & \\
\hline 3 & $\mathrm{Mel} \mathrm{Me1^{+ }}$ & $785 \times 1043$ & \\
\hline 4 & $\mathrm{Mel} / \mathrm{MeI}^{+}$ & $1154 \times 1043$ & \\
\hline \multirow[t]{2}{*}{5} & $\mathrm{Mel}^{\mathrm{Mel}}{ }^{+}$ & $5219 \times 1043$ & \\
\hline & $N$ & Nirvin & N/Meloidogyne incognita \\
\hline
\end{tabular}


of 50 or fewer eggs/g of root), tests were repeated for further verification.

Evaluating the potential of local $M$. incognita population to overcome $\mathrm{Me1}$ and $\mathrm{Me} 3$ resistance. To validate the resistance response of $\mathrm{MeI}$ - and $\mathrm{Me3}$-carrying plants under real agronomic conditions and high inoculum pressure, a bed construction was designed in which individual pots were flanked with Pal-Rig netting (Naot Agricultural Business Society Ltd., Neot Mordechai, Israel) to allow free nematode migration but prevent root passage (Fig. 6). Each pot was filled with 40 liters of loamy soil, which was inoculated with 30,000 eggs of the avirulent isolate Mi2010. Seven- to eight-weekold plants (8 to 10 true leaves) produced in climate-controlled chambers were transplanted into each subdivided pot, with susceptible 'Maor' plants placed between the two resistant lines 1094 (Me1/ $\left.\mathrm{MeI}^{+}\right)$and $1093\left(\mathrm{Me}^{2} / \mathrm{Me}^{+}\right)$in alteration, ensuring high continuous inoculum pressure. The whole experiment was carried out in a protected tunnel belonging to Research Station South (southern Israel). The tunnel was $224 \mathrm{~m}^{2}(28 \mathrm{~m} \times 8 \mathrm{~m})$. A four-bed construction was designed, consisting of five replications for each resistance line $(n=20)$. Six months after inoculation (summer season), plants were removed and carefully washed of soil. GI and egg production were evaluated for each root system. The experiment was repeated twice, producing similar results.
Statistical analysis. All statistical analyses were performed using JMP Pro 10 computer software (SAS Inc., Cary, NC). Each experiment involve the interaction of plant genotype $\times M$. incognita population was repeated twice, producing similar results and a representative data set is shown.

For experiments studying the interactions of $M$. incognita populations with different hosts, $\mathrm{R}$ genes, and the genetic background, data were subjected to 2-way ANOVA. For experiments studying the effect of $M e 3$ allelic stage, gene pyramiding and $\mathrm{R}$ gene durability data were subjected to one way ANOVA. The accumulated data were separated using the Tukey-Kramer multiple comparison test, $P<0.05$, to determine the significance of mean differences among pepper genotype or host plant-nematode isolate combinations. Galling indexes were subjected to nonparametric comparison using Wilcoxon method (Hollander and Wolfe 1973).

\section{Results}

Pathogenic variability among isolates of $M$. incognita according to differential host range test. A wide range of variation in host reactions to $M$. incognita populations was evident among the isolates (Fig. 1). In general, when tomato plants (cv. Avigail) were used as the tested host, the highest GI and egg production rate was measured, followed by tobacco (cv. Samsun NN) plants (Fig. 1). While GIs and
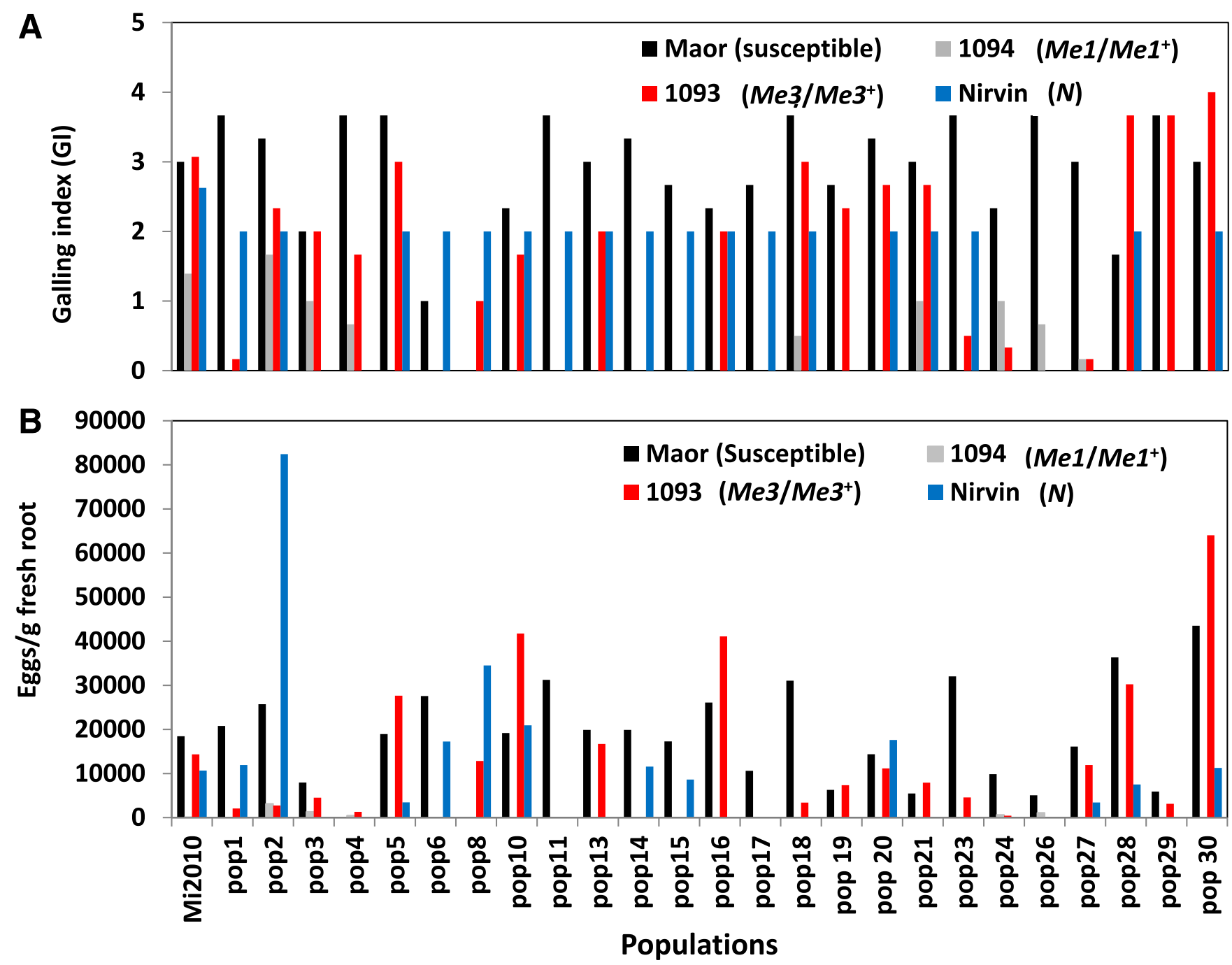

Fig. 2. Response of resistant lines carrying $M e 1, M e 3$, and $N$ to local $M$. incognita populations collected throughout this study. Accessions lines $1094\left(M e 1 / M e 1^{+}\right)$and $1043(M e 3 /$ $\mathrm{Me}^{+}$), and commercial line Nirvin F1 ( $M$ ) (Rijk Zwaan) were the sources for Me1, Me3, and N, respectively, and Maor was the susceptible cultivar; $25 \mathrm{M}$. incognita populations (Table 2) were used in the infection tests. Infected plants were maintained for 2 months after inoculation with 3,000 eggs per plant in a pot experiment conducted in a growth chamber. For nematode disease evaluation, galling by each population was scored on each root system $(\mathbf{A})$ and egg extraction was used to evaluate reproduction on each host-nematode population combination (B). Four replicates of five plants per replicate $(n=20)$ were arranged in a randomized complete block design consisting of each accession line $\times$ population combination. Results obtained from each block were not significantly different and data were pooled together for analysis $(P>0.2405)$. 
egg production rate on pepper were characterized by relatively lower scores than on tomato plants, all 25 populations reproduced well on the former (Fig. 1). Differences among populations were indicated by host status, as observed for pops 5 and 25, which reproduced moderately well on melon (cv. Lavi Gal), pepper, and tobacco, but did not infect tomato, whereas pop 26 did not reproduce on melon (Fig. 1). Examination of cotton (cv. Acala Rav-On 439) host suitability indicated that five populations-pop1, pop2, pop25, pop28, and pop29-could induce disease symptoms and reproduce on cotton plants (Fig. 1). To confirm reproduction ability on cotton by several populations, the host test with cotton was repeated twice, producing similar results. Root galling was also observed in the reaction of cotton with $M$. javanica $\mathrm{Mj} 2010$, the control isolate, as indicated in Figure 1. No galling or egg production were observed on peanut plants by any of the tested populations (Fig. 1). Interpretation of the host differential test results suggested that all $M$. incognita populations studied through the current research belong to $M$. incognita race 2 . The interaction between the block and treatment level was not significant $(P>0.6402)$, indicating that plants hosts have the same effect on respective population in every block.

Variation in virulence of $M$. incognita populations toward genotypes carrying $\mathrm{Me1}, \mathrm{Me3}$, and $\mathrm{N}$ genes. Three pepper genotypes with different $\mathrm{R}$ genes were analyzed for their response to the $M$. incognita populations collected in this study. All of the tested populations induced disease symptoms on roots of the susceptible 'Maor' line, resulting in GI scores ranging from 1 for pop6 to 3.66 for several other populations (Fig. 2). The number of eggs per gram of fresh root produced on the susceptible line ranged from 5,075 by pop26 to 40,332 by pop30 (Fig. 2). Among the three genotypes carrying an $\mathrm{R}$ gene, there was wide variation in disease occurrence with the tested populations. For accession $1093\left(\mathrm{Me}^{2} / \mathrm{Me}^{+}\right)$, reproductive indices ranged from 440 eggs per gram fresh root for pop24 to 64,000 for pop30, while pop6, pop11, pop14, pop15, pop17, and pop26 were unable to reproduce on this line. For the pepper line carrying $\mathrm{Mel}$, GI ranged from 0 for most of the populations, with a maximum 1.66 induced by pop2; however, very limited reproduction was
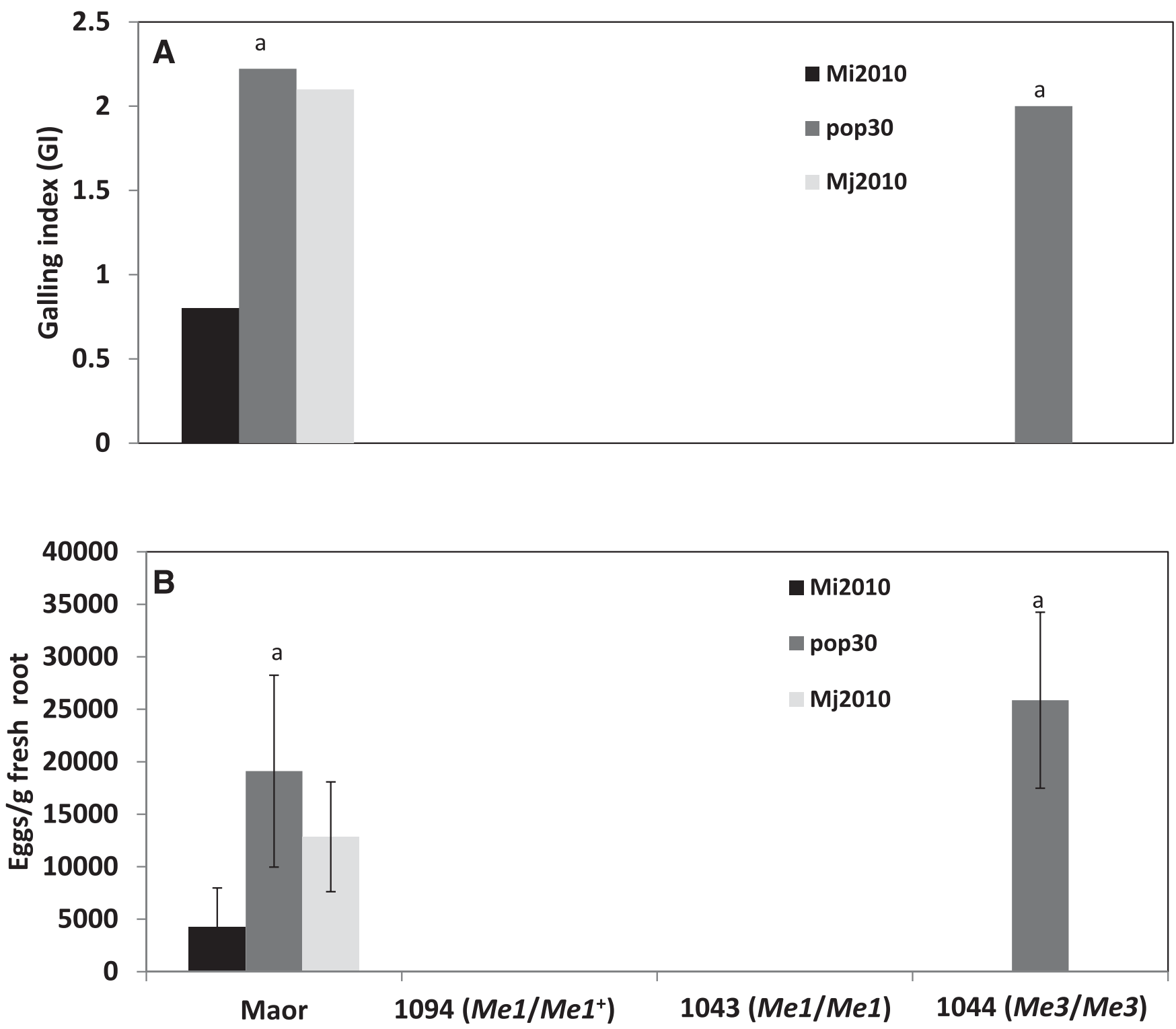

Fig. 3. Effect of $M e 1$ and $M e 3$ allelic stage on resistant/susceptible behavior toward $M$. incognita populations. To evaluate the impact of allelic condition on the reproduction of $M$. incognita populations, susceptible line 'Maor', an F1 hybrid heterozygous for Me1 (1094; Me1/Me1+), a fixed line homozygous for Me1 (1043; Me1/Me1), and a fixed line homozygous for Me3 (1044; Me3/Me3) were evaluated for their response to three different populations: M. incognita Mi2010, pop30, and an M. javanica Mi2010 population. Average $\mathrm{Gl}$ scores (A) and average number of eggs per gram of fresh root (B) were evaluated. Four replicates of five plants per replicate $(n=20)$ were tested for each accession line $\times$ Meloidogyne population combination (mean $\pm \mathrm{SD}$ ). Different letters above the bars denote significant differences $(P \leq 0.05$ by ANOVA) between accession lines analyzed by Tukey-Kramer multiple comparison tests. 

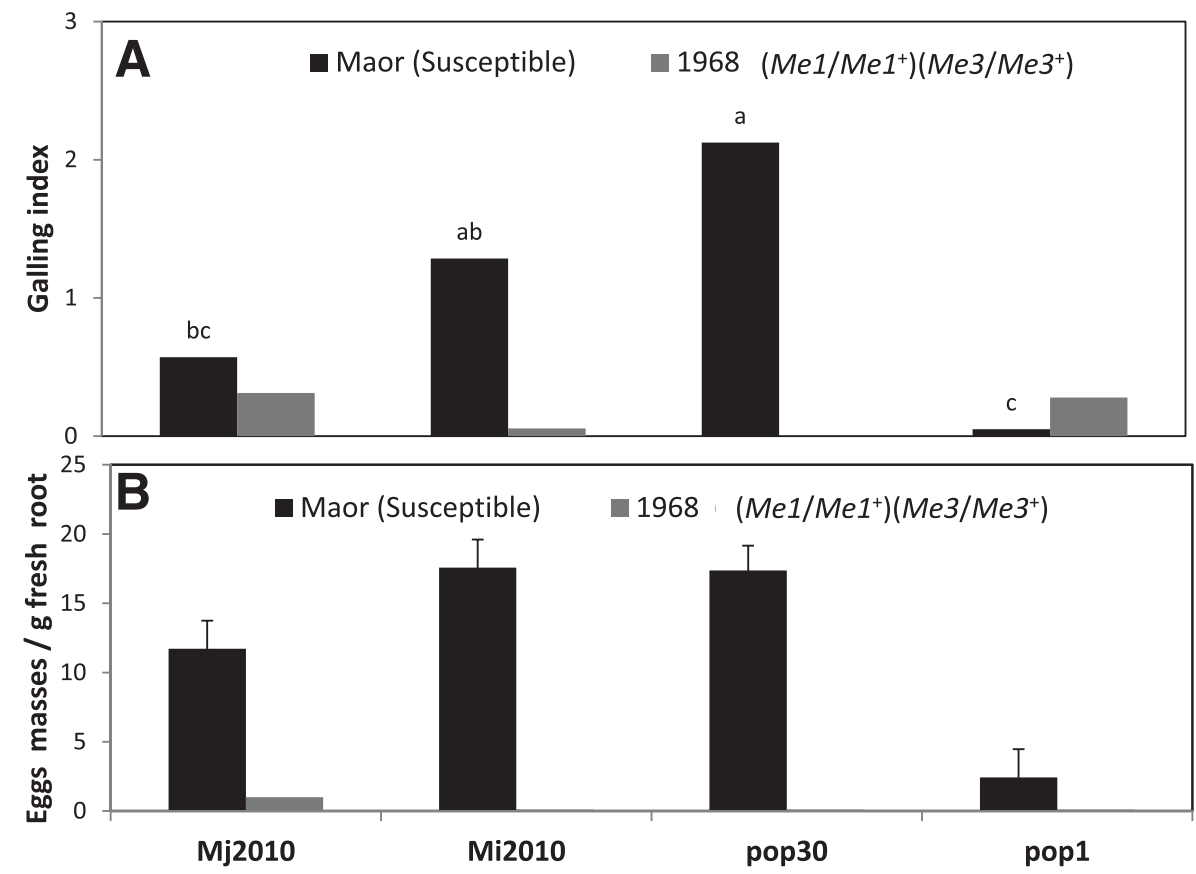

Fig. 4. Me1 and Me3 gene pyramiding. To evaluate the efficiency of Me1 and Me3 gene pyramiding, the F1 hybrid Hetero_1968 was tested for its response to Mi2101, Mij2010, pop30, and pop1 compared with the susceptible 'Maor' line. Plants in pots were inoculated with 3,000 eggs of each nematode population and disease development was evaluated 2 months post inoculation. GI scores (A) and egg masses (B) by Meloidogyne on the roots of both lines are shown. Four replicates of five plants per replicate $(n=20)$ were tested for each accession line $\times$ Meloidogyne population combination (mean \pm SD). Different letters above the bars denote significant differences $(P \leq 0.05$ by ANOVA) between accession lines analyzed by Tukey-Kramer multiple comparison tests.
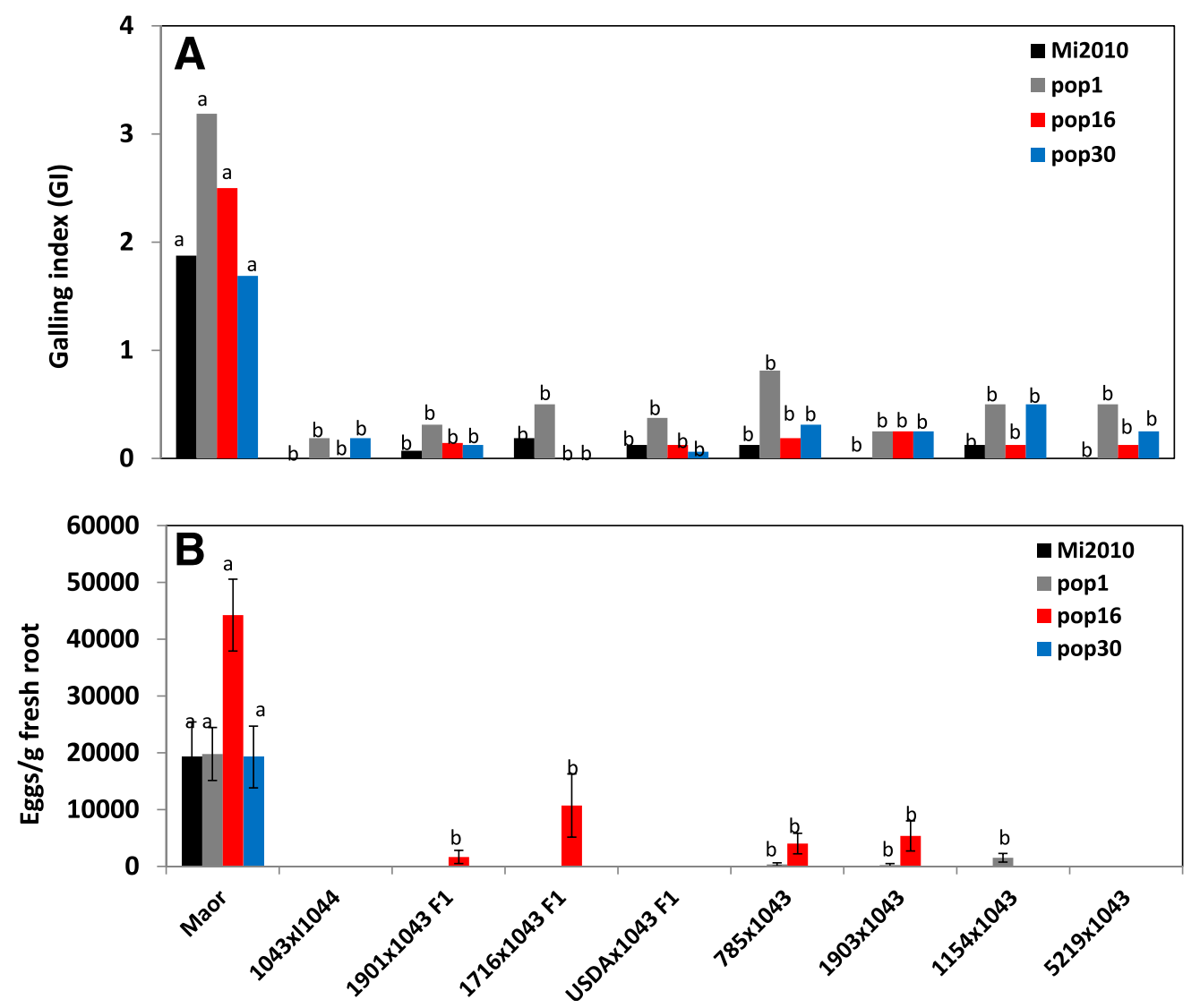

Fig. 5. Effect of the genetic background on Me1 resistance to $M$. incognita populations. Eight different genetic backgrounds were assayed for their response to four RKN populations: Mi2010, pop30, pop1, and pop16. Plants in pots were inoculated with 3,000 eggs of each indicated population and disease development was evaluated 2 months post inoculation, allowing completion of one RKN generation. GI scores (A) and eggs produced (B) by Meloidogyne on the roots of both lines are shown. Four replicates of five plants per replicate $(n=20)$ were arranged in a randomized complete block design consisting of each accession line $\times$ Meloidogyne population combination. Results obtained from each block were not significantly different and data were pooled together for analysis $(P>0.102)$. Different letters above the bars denote significant differences ( $P \leq 0.05$ by ANOVA) between accession lines analyzed by Tukey-Kramer multiple comparison tests. 
observed, only for pop2, pop3, and pop26, with up to 3,127 eggs per gram fresh root (Fig. 2). Resistance of pepper cv. Nirvin, controlled by the $N$ gene, was also studied: root galls were induced by most of the populations, with GIs of 2.0 to 2.62 , while the highest reproduction rate was observed with pop2 (82,412 eggs per gram fresh root). No interaction between the block factor and treatments in relation to GI and egg number $(P>0.2405)$. All inoculation tests were repeated twice, producing similar trends for galling and egg production. The entire data sets from two individual experiments were not combined due to significant statistical differences among the data sets of the same tested interaction $(P<0.05)$, while the results from each individual experiments indicate on similar trend. These results clearly illustrate the inherent variation within this species and the importance of using more than one Meloidogyne isolate to assess $\mathrm{RKN}$ resistance.

Impact of $\mathrm{Me}$ allelic stage, $\mathrm{Me} 1$ and $\mathrm{Me} 3$ gene pyramiding, and genetic background on reproduction of local $M$. incognita populations. Reproduction by the three populations, Mi2010 (M. incognita control isolate), Mj2010 (M. javanica control isolate), and pop30 (population reproduced on cotton plants) could be observed on the susceptible cv. Maor, with no reproduction of any of the populations on either the heterozygous $\left(\mathrm{Mel}^{\mathrm{M}} \mathrm{Me1^{+ }}\right)$ or homozygous (Me1/Me1) Me1-carrying lines (Fig. 3). However, lines carrying two alleles of $\mathrm{Me} 3$ (accession 1044) successfully blocked reproduction of Mi2010 and Mj2010 but did allow reproduction of pop30, originating from a plot in the HaBikha region, where a new cultivar carrying the $N$ gene was growing (Fig. 3). To assess the efficiency of $\mathrm{Mel}$ and $\mathrm{Me} 3$ gene pyramiding, the F1 hybrid Hetero_1968 was tested for its response to Mi2010, Mj2010, pop30, and pop1. None of the tested $M$. incognita populations was able to reproduce on Hetero_1968 plants (Fig. 4).

Given that $M e 1$ demonstrated robust resistance toward $M$. incognita populations, the reaction of several genetic backgrounds in which $M e 1$ is introgressed was studied (Fig. 5). The four populations on the susceptible line 'Maor' exhibited high egg counts of 19,258 to 44,236 eggs per gram fresh root (Fig. 5). Among all tested F1 hybrid genotypes carrying the $\mathrm{Mel}$ allele, considerable resistance to the control avirulent population Mi2010 and pop30 could be observed, with almost no galls produced and no visible reproduction measured (Fig. 5). Limited galling occurrence and reproduction were observed by pop1 and pop16, with low reproduction of pop16 on the heterozygous F1 hybrids carrying Me1: $1901 \times 1043,1716 \times 1043,785 \times$ $1043,1903 \times 1043$, and pop1 on the heterozygous F1, $1154 \times 1043$, indicating that some isolates collected from pepper-production systems can reproduce on certain genetic backgrounds carrying the $\mathrm{Mel}$ allele within a single generation, and illustrating high variation among $M$. incognita populations. Nevertheless, analyzing the response of the $1968(1043 \times 1044)$ lines to the tested populations showed no reproduction of any of these populations. In general, these results indicated that a partially resistant genetic background might be crucial for conferring robust $\mathrm{Mel}$ resistance against a wide range of $M$. incognita populations (Fig. 5). No interaction between block and treatments was calculated $(P>0.102)$. The entire data sets from two individual experiments were not combined due to significant statistical differences among the data sets of the same tested interaction $(P<0.05)$, while the results from each individual experiments indicate on similar trend.

Analysis of ITS sequence diversity among the collected M. incognita populations. To further examine the partitioning of variation in pathogenicity observed among the $M$. incognita populations collected from protected-pepper cropping, we focused on the relatively diverse assemblage of the ITS sequence, using the MITS2 and PM581 set of primers according to Hugall et al. (1999). PCR products of $458 \mathrm{bp}$ were sequenced from all individual isolates. Phylogeny inferred by the MP581 and MITS2 primers across the whole dataset, exhibited extensive sequence similarity, with divergence among the species averaging 5\% across all sequences (Suppl. Fig. $\mathrm{S} 1)$. There was some correlation between the DNA sequences and characterization by differential host test for the respective populations. For example, the phylogenetic tree inferred a specific cluster for the populations shown to reproduce on cotton-pop1, pop2, pop28, and pop29.

Resistance durability of $\mathrm{MeI}$ - and $\mathrm{Me3}$-carrying plants under real agronomic conditions. Finally, the durability of $\mathrm{R}$ genes $\mathrm{Mel}$ and $M e 3$ in accession lines 1094 and 1093, respectively, was assayed against the avirulent $M$. incognita isolate Mi2010 under real agronomic
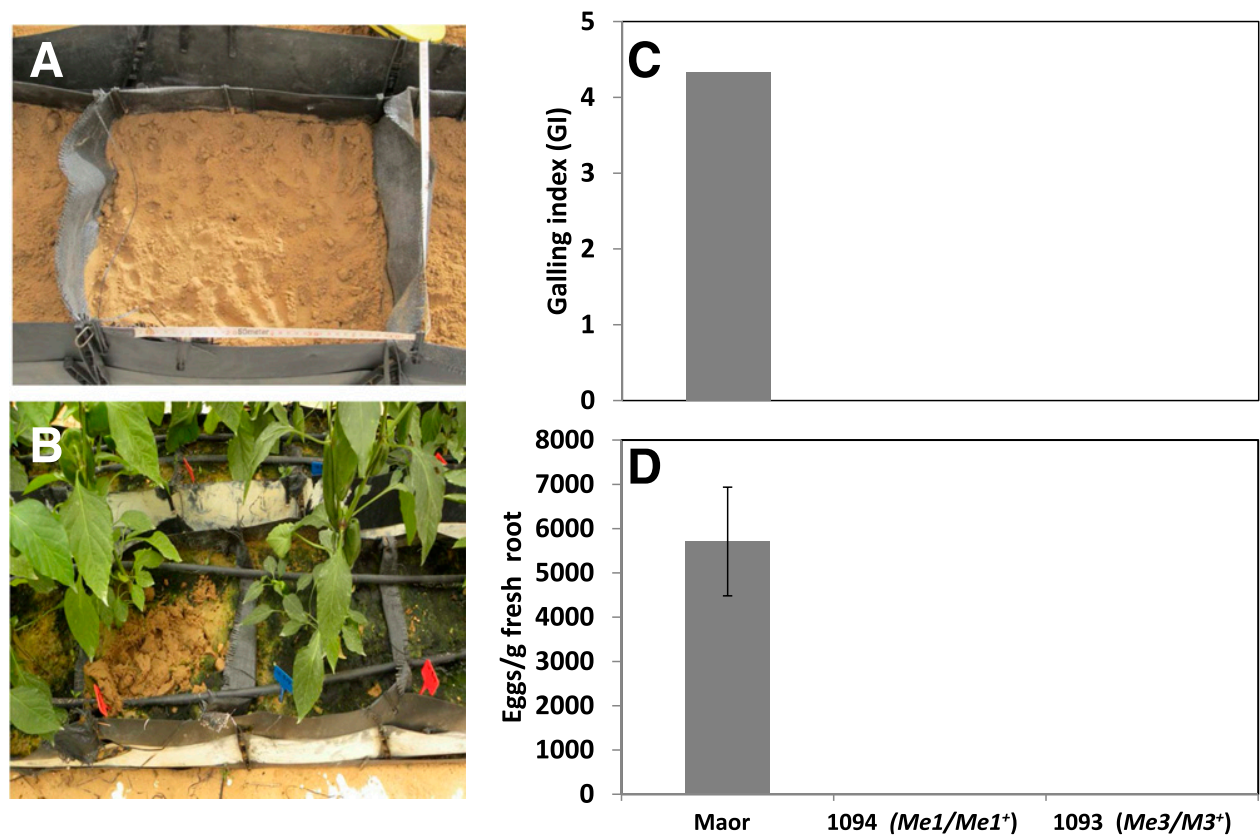

Fig. 6. Effect of continuous inoculum pressure on $\mathrm{Me} 1$ and $\mathrm{Me} 3$ durability under greenhouse conditions. Plants carrying $M e 1$ and $M e 3$ were studied for their response to an avirulent M. incognita population under real agronomic conditions. Susceptible 'Maor' line and accessions 1093 and 1094 carrying Me1 and Me3, respectively, were planted in a pot construction that allowed nematode passage through the pots but prevented root migration between pots. Plants were planted such that susceptible 'Maor' was between resistant lines, thus providing continuous exposure of high inoculum pressure (A, B). At 6 months after planting, root $\mathrm{GI}$ (mean $\pm \mathrm{SD}$ ) (C) and number of eggs per gram of fresh root $(D)($ mean $\pm S D)$ of each pepper line grown in a greenhouse infested with avirulent $M$. incognita were measured. Experiments were repeated twice with similar results. 
conditions. For that purpose continuous inoculum pressure was induced for 6 months (summer crop) in a protected system in subdivided tunnels filled with loamy soil and inoculated with Mi2010 M. incognita control population, as described in Materials and Methods and shown in Figure 6a, b. As expected, the susceptible cv. Maor, cultivated in inoculated plots, exhibited high infestation levels 6 months after infection (GI ranging from 4 to 5). Conversely, neither accession with $\mathrm{R}$ genotypes $\mathrm{Mel}^{\mathrm{MeI}} \mathrm{I}^{+}$and $\mathrm{Me} 3 / \mathrm{Me}^{+}$showed disease symptoms on their root systems (Fig. 6c, d).

\section{Discussion}

Lack of resistance in a commercial line carrying the $N$ gene, as observed in pepper-production systems, was the starting point of this study aimed to assess the extent of divergence in pathogenicity among $M$. incognita populations from local cultivated pepper crops. Findings in this context illustrate that tracking differences among $M$. incognita populations is a prerequisite for successful breeding programs and nematode-management strategies.

Variation in pathogenicity among local $M$. incognita populations from pepper. Results of the differential host tests showed that melon, tomato, tobacco, and pepper are good overall hosts for $M$. incognita populations, whereas peanut was a nonhost. Cotton was slightly infected by five populations and therefore rated as a poor host for them (Fig. 1). Taken together, these results and those from another host test differentiating Meloidogyne races (Barker et al. 1985 ) indicate that all $M$. incognita populations that were collected from pepper-production systems in the current study belong to $M$. incognita race 2 . While the original aim of the differential host test in conjunction with the use of morphological characteristics is to detect host races (Handoo et al. 2004), in this study, we utilized the host differential test to reveal pathogenic variations among $M$. incognita populations that are widely dispersed in protected pepper systems. One of the most striking results from this study was that among the tested populations, reproduction of 5 out of 25 populations could be observed on cotton (Fig. 1). Martin (1954) demonstrated differences in parasitism on cotton among isolates of $M$. incognita, ranging from nonparasitism to severe parasitism, provided early evidence of pathogenic variation within species (Martin 1954). In a later study, Kirkpatrick and Sasser (1983) confirmed that host races 1 and 2 of $M$. incognita do not reproduce well on either susceptible or resistant cotton. However, they indicated that some root galling is induced by some populations, and a low level of reproduction does occur. This might also be the case in the current study, where the five populations that reproduced on cotton implied variation in pathogenicity.

While the observed reproduction of $M$. javanica on susceptible pepper in our study doesn't fit well into the common host differential test (Taylor and Sasser 1978), in the international Meloidogyne project, $7 \%$ of the tested $M$. javanica populations parasitized pepper (Sasser and Carter 1983), potentially supporting our observation of $M$. javanica reproduction on pepper lines. Similarly, while in the original North Carolina differential host test published by Taylor and Sasser (1978), M. javanica did not parasitize cotton, Eisenback and Hirschmann Triantaphyllou (1991) suggested that some populations of $M$. javanica do reproduce on cotton, similar to our results. To test for correlations between the pathogenic profiles observed among the populations and variations in ITS sequences, the primer set MP581 and MITS2 (Hugall et al. 1999), targeted to the relatively diverse assemblage of this sequence, was employed. However, high sequence similarity scores among $M$. incognita populations doesn't support informative phylogenetic analysis. These results emphasize that while use of the differential host test is dated, it still plays an important role in functional characterization of pathogenic variability, particularly when no molecular markers are available to determine race or virulence characteristics within these species.

High variation in $\mathrm{Me1}, \mathrm{Me3}$, and $\mathrm{N} \mathrm{R}$ gene response to $\mathrm{M}$. incognita populations. As shown in this study, host-status suitability of accessions carrying the $\mathrm{Me} 1, \mathrm{Me} 3$, and $\mathrm{N}$ genes for local $M$. incognita populations was highly variable. Among the assayed lines, several populations showed high reproduction rates on plants carrying $\mathrm{Me} 3$ and $N$ genes, whereas reproduction on $\mathrm{Mel}$ plants was strongly inhibited (Fig. 2). These results support previous findings of Castagnone-Sereno et al. (1996) showing that $M$. incognita has a great capacity to respond to environmental selection, even overcoming the known genetic resistance of some hosts. However, while it has been reported that the nematode can overcome the $M e 3 \mathrm{R}$ gene after 5 to 15 generations (Castagnone-Sereno 2006; Castagnone-Sereno et al. 2001), in our study, disease symptoms could be observed by some of the populations on the resistant line in as early as the first generation, suggesting that they are natural populations. Our finding of several $M$. incognita populations not inducing disease symptoms supports previous results in which the response of the pepper cultivars carrying the $\mathrm{Me} 3$ gene seemed to depend on the Meloidogyne population (Djian-Caporalino et al. 2011). Findings here indicate that lines carrying the Mel $\mathrm{R}$ gene provide powerful control against all populations tested. Similarly, Ros-Ibáñez et al. (2014) showed the robustness of $M e 1$, as none of the virulent populations against $M i-1$ resistance gene from tomato and $M e 3$ multiplied on pepper containing the $M e l \mathrm{R}$ gene.

Effects of allelic condition, genetic background, and pyramiding $\mathrm{MeI}$ and $\mathrm{Me3}$. Variations were observed in infection and reproduction rates of the tested populations on the different accessions carrying $\mathrm{Mel}$ (Figs. 3, 4, and 5). This could be attributed to the peppers' genetic backgrounds, as these lines had different progenitors, even though they carried the same $\mathrm{R}$ gene. These results indicated that genetic background should be taken into account in considering practical implications for breeding strategy. Similarly, Jacquet et al. (2005) suggested that when the $M i \mathrm{R}$ gene was introgressed into different tomato genetic backgrounds, the variations in genetic background had a major effect on the variations observed in nematode reproduction. Likewise, Barbary et al. (2014) showed that plant genetic background in pepper plays a crucial role in resistance using the $M$. incognitapepper pathosystem, where a significant effect on reproduction of avirulent $M$. incognita populations was observed. Moreover, Sánchez-Solana et al. (2015) demonstrated that nematode quantitative resistance conferred by the pepper genetic background presents additive effects that are stable against different isolates of $M$. incognita. Taken together, findings support the notion that a partially resistant genetic background may protect $\mathrm{Mel}$ such that it cannot be quickly overcome, thereby increasing the durability of the $\mathrm{Mel} \mathrm{R}$ gene.

In addition to analyzing the effect of genetic background, we questioned whether there is a dosage effect of $\mathrm{Mel}$ and $\mathrm{Me} 3$ alleles on the reproductive potential of local $M$. incognita populations. Similar to previous findings (Barbary et al. 2014), we also demonstrated the lack of a dosage effect for both $\mathrm{Mel}$ and $\mathrm{Me} 3$ alleles on the reproductive potential of RKNs on three tested populations. Our results indicated that while homozygous $\mathrm{Me} 3$ does not confer resistance to pop30 isolated from a pepper-production system, $\mathrm{Mel}$ provides resistance in both the heterozygous and homozygous state (Fig. 3).

Another control strategy that has been used in the last few decades involves combining several $\mathrm{R}$ genes in different plantpathogen systems to improve plant resistance (Gallun and Khush 1980; Hittalmani et al. 2000; Huang et al. 2004; Liu et al. 2000; Nelson 1972). In the current study line, carrying both $\mathrm{Mel}$ and $M e 3$ genes successfully conferred high resistance to pop1 and pop30 isolated from pepper crops (Fig. 4). Similarly, DjianCaporalino et al. (2014) showed that pyramiding of R genes $\mathrm{Mel}$ and $M e 3$ in one genotype suppresses the emergence of virulent isolates. The high resistance of this phenotype might be due to differences in the mechanisms governed by $\mathrm{Me} 1$ and $M e 3 R$ genes (BleveZacheo et al. 1998; Castagnone-Sereno 2006; Pegard et al. 2005) and should be strongly considered as a strategy to manage $M$. incognita in pepper-breeding programs.

Use of $\mathrm{Me1}$ and $\mathrm{Me} 3$ in real farming ecosystems. As the selection of nematode populations that can overcome resistance under natural conditions is favored by the repeated monoculture of cultivars 
carrying R genes (Castagnone-Sereno 2006; Castagnone-Sereno et al. 2001), we explored the durability of both $\mathrm{Mel}$ and $\mathrm{Me} 3$ under continuous high nematode pressure. Under our experimental conditions, starting with high population densities in the soil, which were maintained for the entire experimental period to allow for several nematode generations, the resistance conferred by $\mathrm{Me1}$ and $\mathrm{Me} 3$ against M. incognita control Mi2010 was sustainable.

In conclusion, our study emphasizes the need for primary information concerning the nature and extent of variation in RKNs and the processes by which variants arise for plant-breeding programs to succeed. Our survey showed that not all of the natural populations of $M$. incognita in greenhouses in Israel are equally susceptible to virulence selection on $M e 3$ and $N$ R genes, while none of the populations reproduced on $\mathrm{Mel}$-carrying plants. These results emphasize the advantage of combining several $\mathrm{R}$ genes and certain genetic backgrounds to ensure the durability of the resistance lines. For proper future management of resistance in controlling $M$. incognita in pepper cultivation, factors that may exert selection pressure and influence population variability should be investigated.

\section{Literature Cited}

Barbary, A., Palloix, A., Fazari, A., Marteu, N., Castagnone-Sereno, P., and DjianCaporalino, C. 2014. The plant genetic background affects the efficiency of the pepper major nematode resistance genes $M e 1$ and $M e 3$. Theor. Appl. Genet. 127:499-507.

Barker, K. R., Carter, C. C., and Sasser, J. N. 1985. An Advanced Treatise on Meloidoyne. Volume II: Methodology. Department of Plant Pathology, North Carolina State University, Raleigh, NC

Bleve-Zacheo, T., Bongiovanni, M., Melillo, M. T., and Castagnone-Sereno, P. 1998. The pepper resistance genes $M e 1$ and $M e 3$ induce differential penetration rates and temporal sequences of root cell ultrastructural changes upon nematode infection. Plant Sci. 133:79-90.

Castagnone-Sereno, P. 2006. Genetic variability and adaptive evolution in parthenogenetic root-knot nematodes. Heredity 96:282-289.

Castagnone-Sereno, P., Bongiovanni, M., and Djian-Caporalino, C. 2001. New data on the specificity of the root-knot nematode resistance genes $M e 1$ and Me3 in pepper. Plant Breed. 120:429-433.

Castagnone-Sereno, P., Bongiovanni, M., Palloix, A., and Dalmasso, A. 1996. Selection for Meloidogyne incognita virulence against resistance genes from tomato and pepper and specificity of the virulence/resistance determinants. Eur. J. Plant Pathol. 102:585-590.

Castagnone-Sereno, P., Vanlerberghe-Masutti, F., and Leroy, F. 1994. Genetic polymorphism between and within Meloidogyne species detected with RAPD markers. Genome 37:904-909.

Chitwood, D. J. 2003. Research on plant-parasitic nematode biology conducted by the United States Department of Agriculture-Agricultural Research Service. Pest Manag. Sci. 59:748-753.

Colla, P., Gilardi, G., and Gullino, M. L. 2012. A review and critical analysis of the European situation of soilborne disease management in the vegetable sector. Phytoparasitica 40:515-523.

Djian-Caporalino, C., Molinari, S., Palloix, A., Ciancio, A., Fazari, A., Marteu, N., Ris, N., and Castagnone-Sereno, P. 2011. The reproductive potential of the rootknot nematode Meloidogyne incognita is affected by selection for virulence against major resistance genes from tomato and pepper. Eur. J. Plant Pathol. 131:431-440.

Djian-Caporalino, C., Palloix, A., Fazari, A., Marteu, N., Barbary, A., Abad, P., Sage-Palloix, A. M., Mateille, T., Risso, S., Lanza, R., Taussig, C., and Castagnone-Sereno, P. 2014. Pyramiding, alternating or mixing: comparative performances of deployment strategies of nematode resistance genes to promote plant resistance efficiency and durability. BMC Plant Biol. 14:53.

Djian-Caporalino, C., Pijarowski, L., Januel, A., Lefebvre, V., Daubeze, A., Palloix, A., Dalmasso, A., and Abad, P. 1999. Spectrum of resistance to rootknot nematodes and inheritance of heat-stable resistance in in pepper (Capsicum annuum L.). Theor. Appl. Genet. 99:496-502.

Eisenback, J. D., and Hirschmann Triantaphyllou, H. 1991. Root-knot nematodes: Meloidogyne species and races. Pages 191-274 in: Manual of Agricultural Nematology. W. R. Nickle, ed. Marcel Dekker, Inc., New York.

Fazari, A., Palloix, A., Wang, L. H., Hua, M. Y., Sage-Palloix, A. M., Zhang, B. X., and Djian-Caporalino, C. 2012. The root-knot nematode resistance Ngene co-localizes in the Me-genes cluster on the pepper (Capsicum annuиm L.) P9 chromosome. Plant Breed. 131:665-673.

Gallun, R. L., and Khush, G. S. 1980. Genetic factors affecting expression and stability of resistance. Pages 63-68 in: Breeding Plant Resistance to Insects. F. G. Maxwell and P. R. Jennings, eds. Wiley, New York.
Handoo, Z. A., Nyczepir, A. P., Esmenjaud, D., van der Beek, J. G., CastagnoneSereno, P., Carta, L. K., Skantar, A. M., and Higgins, J. A. 2004. Morphological, molecular, and differential-host characterization of Meloidogyne floridensis $\mathrm{n}$. $\mathrm{sp}$. (Nematoda: Meloidogynidae), a root-knot nematode parasitizing peach in Florida. J. Nematol. 36:20-35.

Hare, W. W. 1956. Resistance in pepper to Meloidogyne incognita-Acrita. Phytopathology 46:98-104.

Hartman, K. L. 1983. Enhancement technique for staining egg masses of the rootknot nematode with Phloxine B. Page 130 in: Proceedings of the Third Research and Planning Conference on Root Knot Nematodes, Meloidogyne spp., Lima, Peru. C. C. Carter and J. N. Sasser, eds. North Carolina State University Graphics, Raleigh, NC.

Hendy, H., Dalmasso, A., and Cardin, M. C. 1985. Differences in resistant Capsicum annuum attacked by different Meloidogyne species. Nematologica 31:72-78.

Hittalmani, S., Parco, A., Mew, T. V., Zeigler, R. S., and Huang, N. 2000. Fine mapping and DNA marker-assisted pyramiding of the three major genes for blast resistance in rice. Theor. Appl. Genet. 100:1121-1128.

Hollander, M., and Wolfe, D. A., eds. 1973. Nonparametric Statistical Methods. John Wiley and Sons, New York.

Huang, N., Angeles, E. R., Domingo, J., Magpantay, G., Singh, S., Zhang, G., Kumaravadivel, N., Bennett, J., and Khush, G. S. 2004. Pyramiding of bacterial blight resistance genes in rice: marker-assisted selection using RFLP and PCR. Theor. Appl. Genet. 95:313-320.

Hugall, A., Stanton, J., and Moritz, C. 1999. Reticulate evolution and the origins of ribosomal internal transcribed spacer diversity in apomictic Meloidogyne. Mol. Biol. Evol. 16:157-164

Hussey, R. S., and Barker, K. R. 1973. Comparison of methods of collecting inocula for Meloidogyne spp., including a new technique. Plant Dis. Rep. 57 1025-1028.

Jacquet, M., Bongiovanni, M., Martinez, M., Verschave, P., Wajnberg, E., and Castagnone-Sereno, P. 2005. Variation in resistance to the root-knot nematode Meloidogyne incognita in tomato genotypes bearing the Mi gene. Plant Pathol. 54:93-99.

Khan, M. W., and Haider, S. R. 1991. Interaction of Meloidogyne javanica with different races of Meloidogyne incognita. J. Nematol. 23:298-305.

Kirkpatrick, T. L., and Sasser, J. N. 1983. Parasitic variability of Meloidogyne incognita populations on susceptible and resistant cotton. J. Nematol. 15: 302-307.

Koenning, S., Overstreet, C., Noling, J., Donald, P., Becker, J., and Fortnum, B. 1999. Survey of crop losses in response to phytoparasitic nematodes in the United States for 1994. J. Nematol. 31:587.

Liu, J., Liu, D., Tao, W., Li, W., Wang, S., Chen, P., Cheng, S., and Gao, D. 2000 Molecular marker-facilitated pyramiding of different genes for powdery mildew resistance in wheat. Plant Breed. 119:21-24.

Martin, W. J. 1954. Parasitic races of Meloidogyne incognita and M. incognita var. acrita. Plant Dis. Rep. Suppl. 227:86-88.

Nelson, R. R. 1972. Stabilizing racial populations of plant pathogens by use of resistance genes. J. Environ. Qual. 1:220-227.

Oka, Y., Offenbach, R., and Pivonia, S. 2004. Pepper rootstock graft compatibility and response to Meloidogyne javanica and M. incognita. J. Nematol. 36: 137-141.

Pegard, A., Brizzard, G., Fazari, A., Soucaze, O., Abad, P., and Djian-Caporalino, C. 2005. Histological characterization of resistance to different root-knot nematode species related to phenolics accumulation in Capsicum annuum. Phytopathology 95:158-165.

Petrillo, M. D., and Roberts, P. A. 2005. Fitness of virulent Meloidogyne incognita isolates on susceptible and resistant cowpea. J. Nematol. 37: 457-466.

Riggs, R. D., and Winstead, N. N. 1959. Studies on resistance in tomato to rootknot nematodes and on the occurrence of pathogenic biotypes. Phytopathology 49:716-724.

Ros-Ibáñez, C., Robertson, L., del Carmen Martinez-Lluch, M., Cano-García, A., and Lacasa-Plasencia, A. 2014. Development of virulence to Meloidogyne incognita on resistant pepper rootstocks. Span. J. Agric. Res. 12:225-232.

Sánchez-Solana, F., Ros, C., Lacasa, C. M., Palloix, A., and Lacasa, A. 2015 Nematode quantitative resistance conferred by the pepper genetic background presents additive effects and is stable against different isolates of Meloidogyne incognita. Plant Pathol. 65:673-681.

Sano, Z., and Iwahori, H. 2005. Regional variation in pathogenicity of Meloidogyne incognita populations on sweetpotato in Kyushu Okinawa, Japan. Jpn. J. Nematol. 35:1-12.

Sasser, J. N., and Carter, C. C. 1983. The international Meloidogyne project: a model for international collaborative research. Arab J. Plant Prot. 1: 48-50.

Southards, C. J., and Priest, M. F. 1973. Variation in pathogenicity of seventeen isolates of Meloidogyne incognita. J. Nematol. 5:63-67.

Swanson, T. A., and Van Gundy, S. D. 1984. Variability in reproduction of four races of Meloidogyne incognita on two cultivars of soybean. J. Nematol. 16: 368-371.

Taylor, A. L., and Sasser, J. N. 1978. Biology, Identification and Control of Rootknot Nematodes (Meloidogyne Species). North Carolina State University Graphics, Raleigh, NC. 
Taylor, D. P., and Netscher, C. 1974. An improved technique for preparing perineal patterns of Meloidogyne spp. Nematologica 20:268-269.

Thies, J. A. 2011. Virulence of Meloidogyne incognita to expression of $N$ gene in pepper. J. Nematol. 43:90-94.

Thompson, J. D., Higgins, D. G., and Gibson, T. J. 1994. CLUSTAL W: improving the sensitivity of progressive multiple sequence alignment through sequence weighting, position-specific gap penalties and weight matrix choice. Nucleic Acids Res. 22:4673-4680.
Triantaphyllou, A. C. 1984. Polyploidy in meiotic parthenogenetic populations of Meloidogyne hapla and a mechanism of conversion to diploidy. Rev. Nematol. 7:62-72. Weingartner, D. P., Smart, G. C., and Schumaker, J. R. 1980. Population dynamics of trichodorid nematodes in Florida Irish potato soils following soil fumigation. J. Nematol. 12:241.

Zijlstra, C., Donkers-Venne, D. T. H. M., and Fargette, M. 2000. Identification of Meloidogyne incognita, $M$. javanica and $M$. arenaria using sequence characterised amplified region (SCAR) based PCR assays. Nematology 2:847-853. 